\title{
Informação aos leitores de Estudos Avançados
}

A editoria de Estudos Avançados informa a seus leitores que recebeu correspondência dos autores Luiz Lehmann Coutinho e Millor Fernandes do Rosário, datada de 9 de dezembro de 2010, informando que, "por engano na submissão do arquivo final", deixaram de incluir o nome de Erika Cristina Jorge, professora-adjunta do Departamento de Morfologia do Instituto de Ciências Biológicas da Universidade Federal de Minas Gerais (UFMG) (@ - ecjorge@icb.ufmg.br), como co-autora do artigo "Biotecnologia animal", publicado no v.24/n.70, pp. 123-147, 2010, do periódico. 